\title{
АНАЛИЗ ЗАКОНОМЕРНОСТЕЙ РАСПРЕДЕЛЕНИЯ АЛЛЕЛЕЙ АВЕНИН-КОДИРУЮЩИХ ЛОКУСОВ У СОРТОВ ОВСА ПОСЕВНОГО ОТЕЧЕСТВЕННОЙ СЕЛЕКЦИИ
}

\author{
A.V. Lyubimova, D.I. Eremin
}

\section{THE ANALYSIS OF REGULARITIES OF DISTRIBUTION OF ALLELES OF AVENIN-CODING LOCI IN DOMESTIC SELECTION OAT VARIETIES}

Любимова A.B. - канд. биол. наук, науч. сотр. лаб. селекции зернофруражных культур НИИСХ Северного Зауралья - филиала ТюмНЦ СО РАН, Тюменская обл., Тюменский р-н, п. Московский, зав. лаб. сортовой идентификации семян Агробиотехнологического центра Государственного аграрного университета Северного Зауралья, г. Тюмень.

E-mail: ostapenkoav88@yandex.ru

Еремин Д.И. - д-р биол. наук, проф. каф. почвоведения и агрохимии Государственного аграрного университета Северного Зауралья, г. Тюмень. E-mail: soil-tyumen@yandex.ru

Проламин-кодирующие локусы успешно применяются в качестве маркерных систем для выявления адаптивно-значимых ассоциаций генов. Проламины овса - авенины - наследуются группами и контролируются тремя независимыми локусами: Avn A, Avn B, Avn C. Цель исследования - изучение связи между географфическим распределением аллелей авенин-кодирующих локусов у образцов овса и природно-климатическими фракторами для выявления аллелей-маркеров адаптивно-значимых ассоциаций генов. Материалом для исследования послужили индивидуальные зерновки 39 сортов и линий овса посевного российской селекции различного эколого-географичческого происхождения. Установлено, что 14 образцов были гомогенными по компонентному составу авенина. Остальные образцы содержали от 2 до 9 биотипов. Группы образцов происхождением из разных регионов отличались по частоте встречаемости аллелей АКЛ. Среди аллелей локуса Avn A самым распространенным был A2, по локусу Avn B наибольшей частотой встречаемости характеризовались аллели В1 u B4. Из аллелей локуса Avn C максимальную частоту встречаемости имели С2, С3 и С1.
Lyubimova A.V. - Cand. Biol. Sci., Staff Scientist, Lab. of selection of Grain Forage Crops, RDIA, Northern Trans-Urals - Tyumen Branch RC SB RAS, Tyumen Region, Tyumen District, $\mathrm{S}$. Moskovsky, Head, Lab. of High-Quality Identification of Seeds, Agrobiotechnological Center, State Agrarian University of Northern Trans-Urals, Tyumen.

E-mail: ostapenkoav88@yandex.ru

Eremin D.I. - Dr. Biol. Sci., Prof., Chair of Soil Science and Agrochemistry, State Agrarian University of Northern Trans-Urals, Tyumen.

E-mail: soil-tyumen@yandex.ru

Выявлено 6 групп регионов, где в процессе селекции получают сорта со схожим аллельным составом АКЛ. Установлено, что выделенные группы достоверно отличались по частоте встречаемости 11 аллелей АКЛ: A1, A2, A4, A7, B1, B2, B3, B4, C5, С6а и С7. Эти аллели являются перспективными для использования в качестве маркеров адаптивно-значимых признаков. Установлено, что аллель A1 выступаem маркером влаголюбивого генотипа, В2 и С6 - маркируют засухоустойчивые генотипы. Аллели C3 и C5 маркируют теплолюбивые генотипы, а аллель С6а - генотип, предпочитающий прохладный и влажный климат. Аллели локуса Avn C играют наибольшую роль 8 процессе приспособляемости особей и маркировании генетических систем, детерминирующих выраженность адаптивно-значимых признаков.

Ключевые слова: овес, электрофоорез, авенин-кодирующие локусы, маркерная селекция.

Prolamin-coding loci have been successfully used as marker systems to identify adaptively significant gene associations. Oat prolamins avenins are inherited by groups and controlled by three in- 
dependent loci: Avn A, Avn B, Avn C. The aim of the research was to study the relationship between geographical distribution of alleles of avenin-coding loci in oat samples and natural and climatic factors to identify alleles-markers of adaptively significant gene associations. The materials for the study were individual grains of 39 varieties and lines of oats of Russian selection of different ecological and geographical origin. It was found out that 14 samples had been homogeneous in the component composition of avenin. The remaining samples contained from 2 to 9 biotypes. The groups of samples originating from different regions differed in the frequency of occurrence of ACL alleles. Among the alleles of Avn A locus, A2 was the most common, and $B 1$ and $B 4$ alleles were characterized by the highest frequency of occurrence at Avn B locus. Of the alleles of Avn C locus, C2, C3, and C1 had the highest incidence. 6 groups of regions were identified, where the varieties with similar allelic composition of ACL were obtained in the process of selection. It was found out that isolated groups significantly differed in the frequency of occurrence of 11 alleles A CL: A1, A2, A4, A7, B1, B2, B3, B4, C5, $\mathrm{C} 6 \mathrm{a}$ and $\mathrm{C7}$. These alleles are promising for using as markers of adaptively significant traits. It was established that $A 1$ allele acted as a marker of moisture-loving genotype, B2 and C6 mark drought-resistant genotypes. Alleles C3 and C5 mark thermophilic genotypes, and allele C6a genotype, preferring cool and humid climate. The alleles of Avn C locus play the greatest role in the process of adaptation of individuals and in the marking of genetic systems that determine the severity of adaptively significant traits.

Keywords: oats, electrophoresis, avenin-coding loci, marker selection.

Введение. Овес посевной (Avena sativa L.) ценная сельскохозяйственная культура, возделываемая на кормовые и зернофуражные цели, а также для питания человека.

Важнейшее направление в селекции овса увеличение урожайности и повышение устойчивости сортов к биотическим и абиотическим факторам среды, а также улучшение их качественных характеристик. Большое значение при создании новых сортов имеет правильный под- бор исходного материала. В настоящее время в селекции все шире применяются не только традиционные способы, но и достижения генетики и биотехнологии. На большом количестве примеров показана пригодность использования разнообразных маркерных систем для выявления адаптивно-значимых ассоциаций генов. Такой анализ основан на оценке динамики частот аллелей маркерных локусов [1]. Очень эффрективны для решения этих задач биохимические маркеры, в том числе спирторастворимые белки семян - проламины [2-5]. Установлена зависимость частоты встречаемости аллелей глиадинкодирующих локусов пшеницы и гордеинкодирующих локусов ячменя от климатических и почвенных условий [6-8]. Проламины овса называются авенинами. Компоненты авенина наследуются группами и контролируются тремя независимыми локусами: Avn A, Avn B, Avn C [9].

Известно, что сочетание аллелей авенинкодирующих локусов (АКЛ) в генотипах носит неслучайный характер. В.А. Портянко установлена географическая зональность во встречаемости аллелей АКЛ у европейских сортов овса, а Х.А. Юмагузиной и В.В. Бахтияровой выявлено значительное сходство в спектрах авенинов сортов, обладающих идентичными биологическими и хозяйственно-ценными признаками. Это свидетельствует, что аллели АКЛ или сцепленные с ними локусы отличаются по своей адаптивной и селекционной ценности [9-11]. Однако в литературе практически отсутствуют сведения о связи между частотой встречаемости аллелей АКЛ и природно-климатическими условиями.

Цель исследования: выявление связи между географическим распределением аллелей авенин-кодирующих локусов у образцов овса российской селекции и природно-климатическими факторами для выявления аллелей-маркеров адаптивно-значимых ассоциаций генов.

Материалы и методы исследования. Исследование осуществляли в лаборатории сортовой идентификации семян Государственного аграрного университета Северного Зауралья. Материалом для исследований послужили 39 сортов и линий овса посевного российской селекции различного эколого-географического происхождения (табл. 1, 2). 
Исследованные образцы овса посевного

\begin{tabular}{|c|c|c|c|}
\hline Сорт & Происхождение & Сорт & Происхождение \\
\hline Аргумент & Алтайский край & Дедал & Ленинградская обл. \\
\hline Креол & $-"-$ & Борот & -4 \\
\hline Обыкновенный & -" & Соку & -"- \\
\hline M 4000 & -"- & Песец & $-"-$ \\
\hline Тулунский 19 & Иркутская обл. & Атула & -"- \\
\hline Кемеровский 90 & Кемеровская обл. & Гибрид & $-"-$ \\
\hline Мyром & -"- & Успех & $-"-$ \\
\hline Гаврош & -" & Пушкинский & -"- \\
\hline Чиж & Кировская обл. & Привет & Московская обл. \\
\hline Кречет & $-"-$ & Борец & $-"-$ \\
\hline Эклинс & $-"-$ & Краснообский & Новосибирская обл. \\
\hline Вятский голозерный & $-"-$ & Мутика 556 & Омская обл. \\
\hline Першерон & -"- & Сибирский кормовой & -"- \\
\hline Вятский & -"- & Васехадка 298 & Сахалинская обл. \\
\hline Траверс & Красноярский край & Универсал 1 & Свердловская обл. \\
\hline Л 1004-6(479) & -"- & Памяти Балавина & -"- \\
\hline Голец & -"- & Спринт 2 & -"- \\
\hline Льговский 9 & Курская обл. & Отрада & Тюменская обл. \\
\hline Льговский & -“- & Талисман & $-"-$ \\
\hline
\end{tabular}

Растительный материал предоставлен из ресурсов растений им. Н.И. Вавилова и НИИСХ коллекции Федерального исследовательского Северного Зауралья - филиалом ФИЦ ТюмНЦ центра Всероссийского института генетических СО РАН.

Таблица 2

Характеристика климатических условий в регионах происхождения образцов овса

\begin{tabular}{|c|c|c|c|c|c|c|c|c|}
\hline Регион & 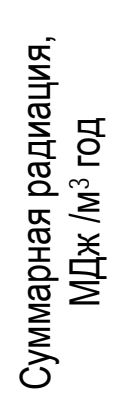 & 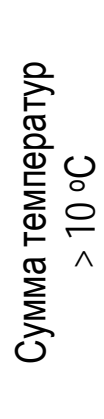 & 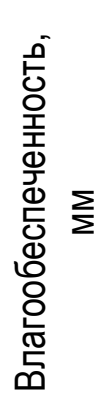 & 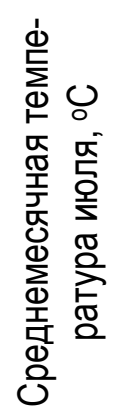 & 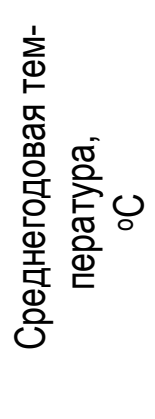 & 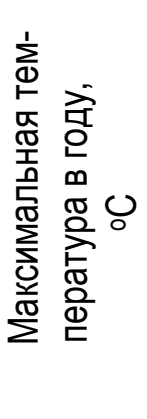 & 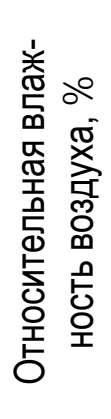 & 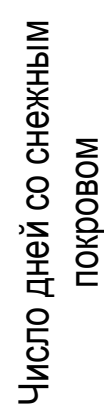 \\
\hline 1 & 2 & 3 & 4 & 5 & 6 & 7 & 8 & 9 \\
\hline Кировская обл. & 3775 & 2000 & 105 & 18 & 1 & 31 & 55 & 162,5 \\
\hline Красноярский край & 3575 & 1400 & 100 & 18 & -5 & 31 & 60 & 212,5 \\
\hline Ленинградская обл. & 3775 & 2000 & 105 & 18 & 3 & 29 & 65 & 137,5 \\
\hline Московская обл. & 3775 & 2000 & 105 & 20 & 3 & 31 & 65 & 137,5 \\
\hline
\end{tabular}




\begin{tabular}{|l|c|c|c|c|c|c|c|c|}
\hline \multicolumn{1}{|c|}{1} & 2 & 3 & 4 & 5 & 6 & 7 & 8 & 9 \\
\hline Свердловская обл. & 3575 & 1400 & 100 & 18 & 0 & 32 & 55 & 162,5 \\
\hline Тюменская обл. & 3575 & 1400 & 100 & 20 & 0 & 34 & 55 & 162,5 \\
\hline Алтайский край & 4625 & 2100 & -250 & 20 & 1 & 34 & 55 & 162,5 \\
\hline Кемеровская обл. & 3575 & 1400 & 100 & 20 & -1 & 33 & 60 & 187,5 \\
\hline Новосибирская обл. & 4625 & 2100 & -250 & 20 & 1 & 34 & 55 & 162,5 \\
\hline Омская обл. & 4625 & 2100 & -250 & 20 & 1 & 34 & 50 & 162,5 \\
\hline Сахалинская обл. & 4175 & 1500 & 100 & 14 & -1 & 25 & 75 & 187,5 \\
\hline Иркутская обл. & 3975 & 950 & 0 & 19 & -4 & 31 & 55 & 212,5 \\
\hline Курская обл. & 3775 & 2000 & 105 & 20 & 7 & 33 & 65 & 112,5 \\
\hline
\end{tabular}

Примечание: таблица составлена с использованием данных Национального атласа России (URL: http://национальныйатлас.рф).

Для анализа методом случайной выборки отбирали по 100 зерновок каждого сорта. Электрофорез проводили по ранее описанной методике [12]. Идентифрикацию аллельных вариантов авенин-кодирующих локусов осуществляли по каталогу, описанному В.А. Портянко [9]. В качестве стандарта использовали зерновки овса посевного сорта Астор (Avn A2 B4 C2).

Для поиска групп образцов со схожим аллельным составом применяли кластеризацию методом Варда и методом k-средних. Связь между частотой встречаемости аллелей авенин-кодирующих локусов и природно-климатическими факторами выявляли с применением коэфффициента ранговой корреляции Спирмена.

Результаты исследования и их обсуждение. В результате проведения электрофоретического анализа установлено, что 14 образцов были гомогенными по компонентному составу авенина. Остальные образцы содержали от 2 до 9 биотипов. Общее число обнаруженных биотипов составило 114 шт. Для выявления связи между аллелями АКЛ и природно-климатическими фракторами необходимо идентифицировать аллели по всем трем локусам для каждого из исследованных биотипов. Однако некоторые из обнаруженных нами блоков компонентов проламина отсутствовали в каталоге генетической номенклатуры, что не позволило идентифицировать контролирующие их аллели АКЛ. Биотипы, для которых не удалось полностью описать генетические формулы авенина, были исключены из дальнейшего исследования. В результате все последующие расчеты проводились на основании данных об аллельном составе 64 биотипов (табл. 3).

\section{Количество исследованных биотипов с известными генетическими формулами авенина}

\begin{tabular}{|l|c|l|c|}
\hline Регион происхождения & Кол-во биотипов & Регион происхождения & Кол-во биотипов \\
\hline Алтайский край & 4 & Московская обл. & 2 \\
\hline Иркутская обл. & 3 & Новосибирская обл. & 2 \\
\hline Кемеровская обл. & 5 & Омская обл. & 2 \\
\hline Кировская обл. & 11 & Сахалинская обл. & 1 \\
\hline Красноярский край & 5 & Свердловская обл. & 6 \\
\hline Курская обл. & 4 & Тюменская обл. & 3 \\
\hline Ленинградская обл. & 16 & & \\
\hline
\end{tabular}

Селекционная работа с овсом направлена на создание высокоурожайных сортов с высоким содержанием белка в зерне, устойчивых к полеганию, засухе, болезням и обладающих экологиче- ской пластичностью. Некоторые из ассоциаций генов, контролирующих проявление этих признаков, могут быть сцеплены с аллелями АКЛ. Для того чтобы выявить группы регионов, где в про- 
цессе селекции выводят сорта со схожим аллельным составом АКЛ, нами была проведена кластеризация методом k-средних. Искомое число конечных кластеров (k) было определено проведе- нием предварительной кластеризации методом Варда и равнялось шести. Результаты кластеризации представлены в таблице 4.

Таблица 4

Кластеры совокупностей образцов овса различного происхождения, выделенные методом k-средних

\begin{tabular}{|c|l|}
\hline Кластер & \multicolumn{1}{|c|}{ Состав (регион происхождения образцов) } \\
\hline 1 & Сахалинская обл. \\
\hline 2 & Тюменская обл. \\
\hline 3 & $\begin{array}{l}\text { Кировская обл., Красноярский край, Курская обл., Ленинградская обл., } \\
\text { Омская обл., Свердловская обл. }\end{array}$ \\
\hline 4 & Алтайский край, Новосибирская обл. \\
\hline 5 & Иркутская обл., Кемеровская обл. \\
\hline 6 & Московская обл. \\
\hline
\end{tabular}

Самую большую группу сфрормировали образцы овса происхождением из Кировской, Курской, Ленинградской, Омской, Свердловской областей и Красноярского края. Эти регионы находятся на большом расстоянии друг от друга и существенно отличаются по природно-климатическим условиям. Преобладание в сортах овса, созданных в их селекционных центрах, одних и тех же аллелей АКЛ может быть вызвано рядом причин. Вопервых, вовлечением в селекционные программы одних и тех же генотипов. Во-вторых, отбором особей с одинаковым или близким аллельным составом АКЛ. На примере пшеницы доказано, что существуют аллели проламин-кодирующих локусов, маркирующие хозяйственно-ценные признаки, такие как высокие качество зерна и технологические свойства муки. Некоторые из таких аллелей-маркеров достаточно широко распространены и могут с высокой частотой встречаться в сортах, созданных в разных селекционных центрах $[13,14]$. По нашему мнению, аллельные варианты АКЛ, встречающиеся с высокой частотой в сортах овса с разным эколого-географическим происхождением, также могут быть маркерами хозяйственно-ценных признаков и представляют интерес для дальнейшего изучения.

Установлено, что некоторые из групп образцов происхождением из разных регионов отличались по частоте встречаемости аллелей АКЛ (рис. 1, 2).

Среди аллелей локуса Avn A самым распространенным был A2 - биотипы с таким вариантом встречались во всех регионах, кроме Сахалинской и Тюменской областей. Аллели А5 и А6 были самыми редкими и обнаружены нами только в образцах происхождением из Новосибирской и Свердловской областей соответственно.

По локусу Avn B наибольшей частотой встречаемости характеризовались аллели $B 1$ и B4. Вариант В5 встречался реже всего. Он выявлен нами в группах образцов происхождением из Московской и Тюменской областей.

Из аллелей локуса Avn C максимальную частоту встречаемости имели С2 (26,6 \%), С3 (20,3 \%) и C1 (18,7 \%). Реже всего встречались аллели С6а (Ленинградская и Сахалинская обл.) и С6b (Кемеровская обл.).

Одной из причин таких отличий может быть неодинаковая адаптивная ценность аллелей авенин-кодирующих локусов. Ряд авторов при изучении проламинов овса отмечали аллели, характерные только для сортов происхождением из конкретных географических регионов $[9,11]$. Это указывает на то, что некоторые из аллелей АКЛ могут быть сцеплены с определенными адаптивнозначимыми генными комплексами. В этом случае при отборе генотипов, наиболее приспособленных к определенным природно-климатическим условиям, одновременно происходит и отбор маркирующих их аллелей проламин-кодирующих локусов. В результате частота встречаемости аллелей АКЛ в образцах овса происхождением из разных регионов может существенно различаться. 


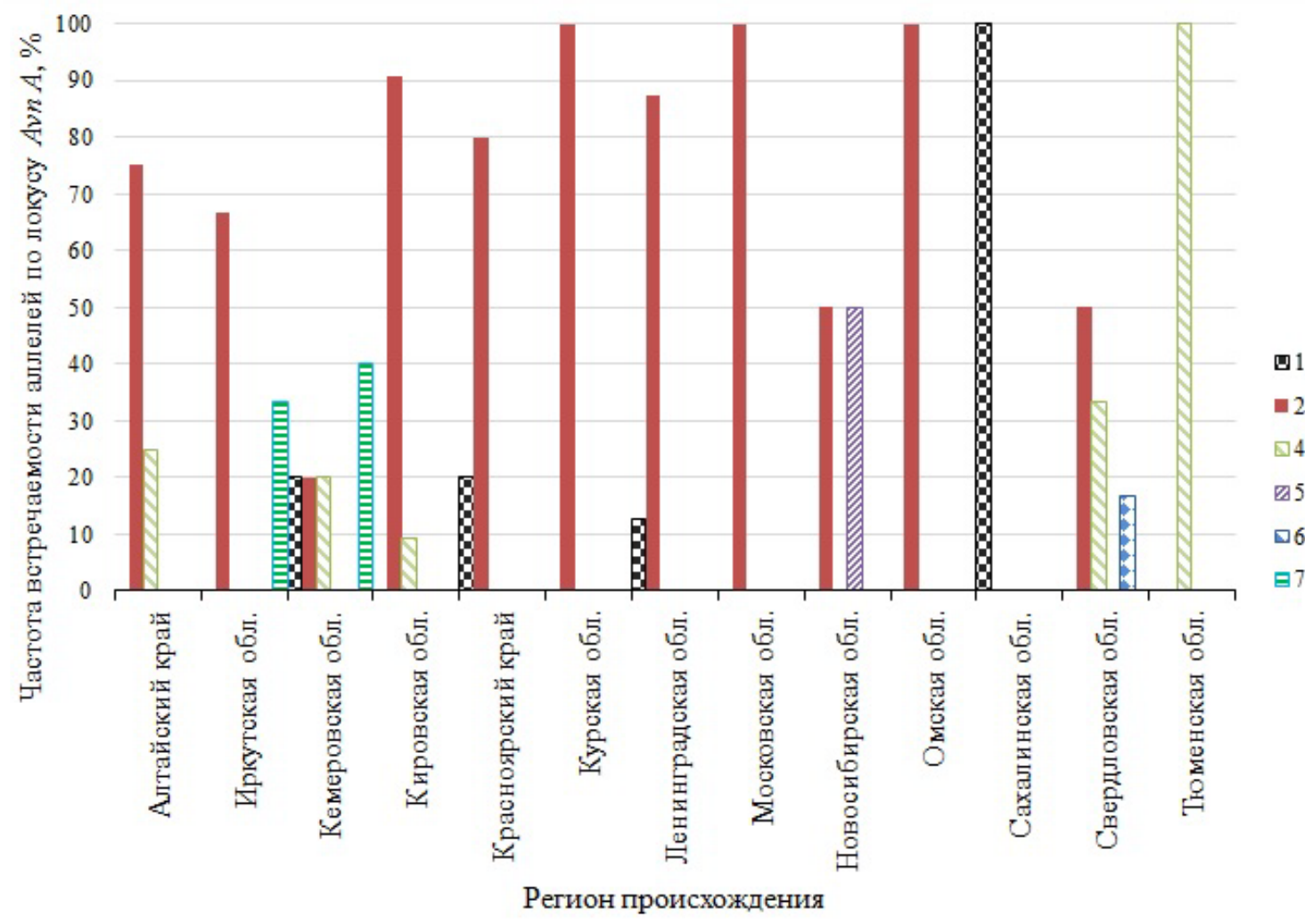

Puc. 1. Частота встречаемости, \%, аллелей локуса Avn A в биотипах овса посевного происхождением из различных регионов: 1-7 - номера аллелей

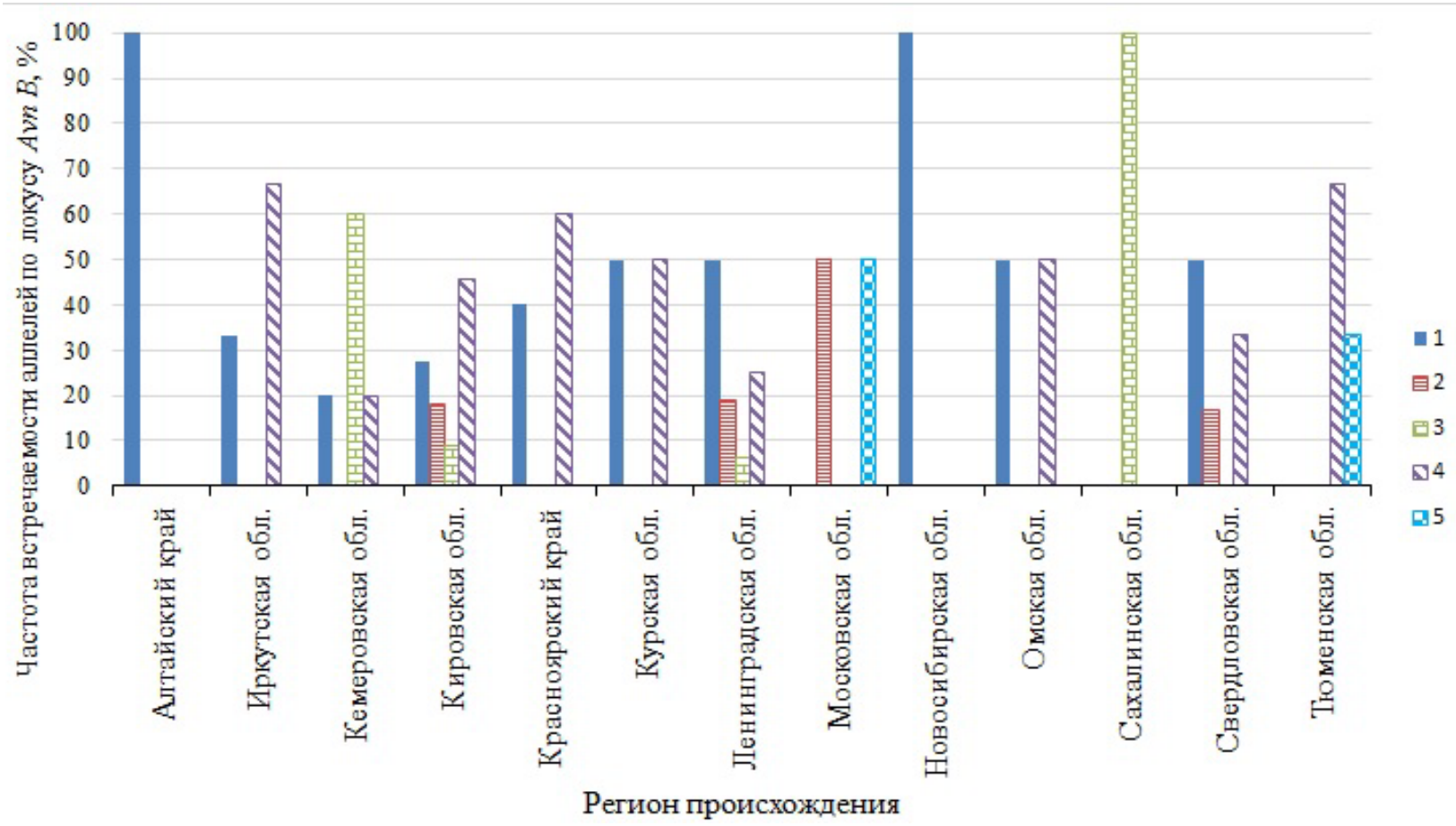

Puc. 2. Частота встречаемости, \%, аллелей локуса Avn B в биотипах овса посевного происхождением из различных регионов: 1-5- номера аллелей

Для того чтобы определить, существует ли связь между частотой встречаемости аллелей авенин-кодирующих локусов и климатическими условиями, описанными в таблице 2, нами был 
применен коэффициент ранговой корреляции Спирмена. Установлено, что частота встречае- мости шести аллелей связана определенными природно-климатическими факторами (табл. 5).

Таблица 5

Коэффициент корреляции частоты встречаемости аллелей АКЛ и природно-климатических факторов (связь существенна при $p<0,05$ )

\begin{tabular}{|c|c|c|c|c|c|c|c|c|}
\hline $\begin{array}{c}\text { Аллель } \\
\text { АКЛ }\end{array}$ & 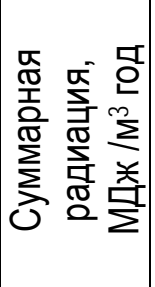 & 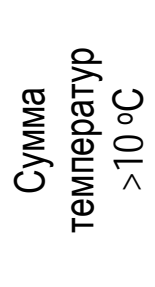 & 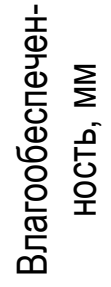 & 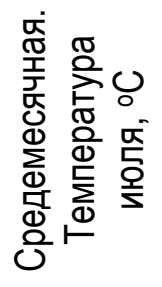 & 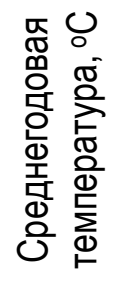 & 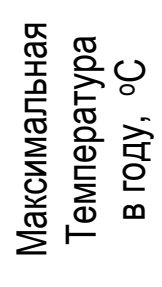 & 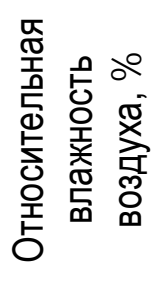 & 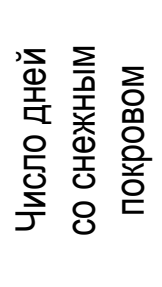 \\
\hline$A 1$ & - & - & - & - & - & - & 0,71 & - \\
\hline$B 2$ & - & - & $-0,67$ & - & - & - & - & - \\
\hline C3 & - & - & - & - & 0,67 & - & - & - \\
\hline C5 & - & 0,60 & - & - & - & - & - & - \\
\hline C6 & - & - & $-0,74$ & - & - & - & $-0,56$ & $-0,69$ \\
\hline C6a & - & - & - & $-0,61$ & - & $-0,65$ & 0,61 & - \\
\hline
\end{tabular}

Выявлено, что аллель $A 1$ может выступать маркером влаголюбивого генотипа, В2 и С6 - засухоустойчивого. Аллели С3 и С5 перспективны в качестве маркеров теплолюбивых генотипов, а аллель С6а - генотипа, предпочитающего прохладный и влажный климат. Большая часть аллелей, связанных с климатическими факторами, принадлежит локусу Avn C. Как известно, характер белкового полиморфизма неоднороден даже внутри одной маркерной системы. По нашему мнению, аллели локуса Avn C играют наибольшую роль в процессе приспособляемости особей и маркировании генетических систем, детерминирующих выраженность адаптивно-значимых признаков.

\section{Выводы}

1. Кластеризацией методом k-средних выделено 6 кластеров, объединяющих группы образцов овса посевного разного географического происхождения со схожим аллельным составом АКЛ. Аллели, встречающиеся с высокой частотой в группах сортов, вошедших в один кластер, могут быть маркерами хозяйственно-ценных признаков и представляют интерес для дальнейшего изучения.

2. Установлено, что частота встречаемости шести аллелей авенин-кодирующих локусов связана с определенными климатическими условия- ми. Аллель $A 1$ может выступать маркером влаголюбивого генотипа, В2 и С6 - засухоустойчивого. Аллели C3 и C5 перспективны в качестве маркеров теплолюбивых генотипов, а аллель С6а - генотипа, предпочитающего прохладный и влажный климат.

3. Аллели локуса Avn C, вероятно, играют наибольшую роль в процессе приспособляемости особей и маркировании генетических систем, детерминирующих выраженность адаптивно-значимых признаков.

\section{Литература}

1. Романова Ю.А., Губарева Н.К., Конарев А.В. Исследование коллекции вида пшеницы Triticum spelta L. по полиморфизму глиадинов // Генетика. - 2001. - Т. 37, № 9. - С. 1258-1265.

2. Перчук И.Н., Конарев А.В., Лоскутов И.Г., Блинова Е.В. и др. Белковые маркеры, морфологические и селекционные признаки в идентификации дублетных образцов культурного овса в коллекциях ВИР (Россия) $и$ нордического генного банка (Nordgen, Швеция) // Тр. по прикладной ботанике, генетике и селекции. - 2016. T. 177. - C. 82-93.

3. Любимова А.В., Ярова Э.Т., Еремин Д.И. Изменение биотипного состава сортов яро- 
вой тритикале в процессе возделывания // Вестн. КрасГАУ. - 2018. - № 5 (140). - С. 3-8.

4. Любимова А.В., Еремин Д.И. Изучение генетического разнообразия сортов овса Сибирской селекции по авенин-кодирующим локусам // Агропродовольственная политика России. - 2017. - № 9 (69). - С. 70-74.

5. Тоболова Г.В. Изменение биотипного состава сорта мягкой пшеницы Тюменская 80 в процессе семеноводства // Аграрный вестник Урала. - 2009. - № 10. - С. 12-14.

6. Новосельская-Драгович А.Ю., Беспалова Л.А., Шишкина А.А., Мельник В.А. и др. Изучение генетического разнообразия сортов мягкой озимой пшеницы по глиадинкодирующим локусам // Генетика. - 2015. - Т. 51, № 3. - С. 324-334.

7. Помориев А.А., Лялина Е.В., Калабушкин Б.А. Гордеин-кодирующие локусы как генетические маркеры у ячменя // Тр. по прикладной ботанике, генетике и селекции. - 2009. T. 165. - C. 32-36.

8. Якубышина Л.И., Казак А.А., Логинов Ю.П. Использование метода электрофореза в семеноводстве ячменя сорта Одесский $100 / /$ Изв. Оренбург. гос. аграр. ун-та. - 2017. № 5 (67). - С. 56-59.

9. Портянко В.А. Генетический контроль и полиморфизм проламина овса: автореф. дис. ... канд. биол. наук. - М., 1987. - 16 с.

10. Юмагузина Х.А., Бахтиярова В.В. Электрофоретические спектры спирторастворимых белков зерна видов и подвидов рода Avena // $\mathrm{V}$ съезд Всесоюзного общества генетиков и селекционеров им. Н.И. Вавилова (Москва, 24-28 ноября 1987 г.): тез. докл. - М., 1987. T. IV. - 4. 4. - C. 322.

11. Souza E., Sorrells M.E. Inheritance and distribution of variation at four avenin loci in North American oat germ plasm // Genome. - 1990. - V. 33, № 3. - P. 416-424.

12. Любимова А.В., Еремин Д.И. Региональные особенности полиморфизма авенинов овса, возделываемого в Западной Сибири // Тр. по прикладной ботанике, генетике и селекции. 2018. - T. 179, № 2. - С. 85-95.

13. Летяго Ю.В., Тоболова Г.В., Белкина Р.И. Оценка сортов мягкой яровой пшеницы по технологическим свойствам и биохимическим признакам // Агропродовольственная политика России. - 2015. - № 5. - С. 64-67.

14. Новосельская-Драгович А.Ю., Фисенко А.В., Имашева А.Г. и др. Сравнительный анализ динамики генетического разнообразия по глиадинкодирующим локусам среди сортов озимой мягкой пшеницы Triticum aestivum L., созданных за 40-летний период научной селекции в Сербии и Италии // Генетика. 2007. - № 43 (11). - С. 1478-1485.

\section{Literatura}

1. Romanova Yu.A., Gubareva N.K., Konarev A.V. Issledovanie kollekcii vida pshenicy Triticum spelta L. po polimorfizmu gliadinov // Genetika. 2001. - T. 37, № 9. - S. 1258-1265.

2. Perchuk I.N., Konarev A.V., Loskutov I.G., Blinova E.V. i dr. Belkovye markery, morfologicheskie i selekcionnye priznaki $\mathrm{v}$ identifikacii dubletnyh obrazcov kul'turnogo ovsa v kollekciyah VIR (Rossiya) i nordicheskogo gennogo banka (Nordgen, Shveciya) // Tr. po prikladnoj botanike, genetike i selekcii. - 2016. T. 177. - S. 82-93.

3. Lyubimova A.V., Yarova E.T., Eremin D.I. Izmenenie biotipnogo sostava sortov yarovoj tritikale $\mathrm{V}$ processe vozdelyvaniya // Vestn. KrasGAU. - 2018. - № 5 (140). - S. 3-8.

4. Lyubimova A.V., Eremin D.I. Izuchenie geneticheskogo raznoobraziya sortov ovsa Sibirskoj selekcii po avenin-kodiruyushchim lokusam II Agroprodovol'stvennaya politika Rossii. - 2017. - № 9 (69). - S. 70-74.

5. Tobolova G.V. Izmenenie biotipnogo sostava sorta myagkoj pshenicy Tyumenskaya $80 \mathrm{v}$ processe semenovodstva // Agrarnyj vestnik Urala. - 2009. - № 10. - S. 12-14.

6. Novosel'skaya-Dragovich A.Yu, Bespalova L.A., Shishkina A.A., Mel'nik V.A. i dr. Izuchenie geneticheskogo raznoobraziya sortov myagkoj ozimoj pshenicy po gliadinkodiruyushchim lokusam // Genetika. - 2015. - T. 51, № 3. S. 324-334.

7. Pomorcev A.A., Lyalina E.V., Kalabushkin B.A. Gordein-kodiruyushchie lokusy kak geneticheskie markery u yachmenya // Tr. po prikladnoj botanike, genetike i selekcii. - 2009. - T. 165. S. 32-36. 
8. Yakubyshina L.I., Kazak A.A., Loginov Yu.P. Ispol'zovanie metoda elektroforeza $V$ semenovodstve yachmenya sorta Odesskij 100 // Izv. Orenburg. gos. agrar. un-ta. - 2017. № 5 (67). - S. 56-59.

9. Portyanko V.A. Geneticheskij kontrol' i polimorfizm prolamina ovsa: avtoref. dis. ... kand. biol. nauk. - M., 1987. - $16 \mathrm{~s}$.

10. Yumaguzina H.A., Bahtiyarova V.V. Elektroforeticheskie spektry spirtorastvorimyh belkov zerna vidov i podvidov roda Avena // V s"ezd Vsesoyuznogo obshchestva genetikov i selekcionerov im. N.I. Vavilova (Moskva, 24-28 noyabrya 1987 g.): tez. dokl. - M., 1987. T. IV. - Ch. 4. - S. 322.

11. Souza E., Sorrells M.E. Inheritance and distribution of variation at four avenin loci in North American oat germ plasm // Genome. - 1990. - V. 33, № 3. - P. 416-424.
12. Lyubimova A.V., Eremin D.I. Regional'nye osobennosti polimorfizma aveninov ovsa, vozdelyvaemogo v Zapadnoj Sibiri // Tr. po prikladnoj botanike, genetike i selekcii. - 2018. T. 179, № 2. - S. 85-95.

13. Letyago Yu.V., Tobolova G.V., Belkina R.I. Ocenka sortov myagkoj yarovoj pshenicy po tekhnologicheskim svojstvam i biohimicheskim priznakam // Agroprodovol'stvennaya politika Rossii. - 2015. - № 5. - S. 64-67.

14. Novosel'skaya-Dragovich A.Yu., Fisenko A.V., Imasheva A.G. i dr. Sravnitel'nyj analiz dinamiki geneticheskogo raznoobraziya po gliadinkodiruyushchim lokusam sredi sortov ozimoj myagkoj pshenicy Triticum aestivum L., sozdannyh za 40-letnij period nauchnoj selekcii v Serbii i Italii // Genetika. - 2007. - № 43 (11). S. 1478-1485. 